Check for updates

Cite this: RSC Adv., 2019, 9, 15370

\title{
The dependence of oxygen sensitivity on the molecular structures of Ir(III) complexes and their application for photostable and reversible luminescent oxygen sensing $\dagger$
}

Yang Xing, (DD a Chengfang Qiao, ${ }^{\mathrm{b}}$ Xinmin Li, ${ }^{\mathrm{c}}$ Chun Li, ${ }^{a}$ Honghao Wang, ${ }^{a}$ Fayun $\mathrm{Li}^{a}{ }^{a}$ Ling Di $\mathbb{D}^{* a d}$ and Zhanxu Yang ${ }^{* a}$

Three $\operatorname{Ir}(\mathrm{III})$ complexes $\operatorname{IrC1}$, IrC2, and IrC3 substituted with 4-(diphenylamino)phenyl (TPA), 4-(9Hcarbazol-9-yl)phenyl (Cz1), and 9-phenyl-9H-carbazol-3-yl (Cz2) moieties were prepared and fully characterized as phosphorescent emitters. In comparison with $\operatorname{Ir}(\mathrm{ppy})_{3}$, introduction of TPA, Cz1, and $\mathrm{Cz} 2$ moieties strongly improved the oxygen sensitivities of $\operatorname{IrC1} 1-\operatorname{IrC} 3$. Short-decayed $\operatorname{IrC1}$ with $I_{0} / /_{100}$ of 168.6 and $K_{S}^{\text {app }}$ of 202.2 bar $^{-1}$ in THF exhibited the highest sensitivity for oxygen. TPA and Cz moieties caused remarkable collision radius variations of the $\operatorname{Ir}\left(\right.$ III) complexes with $2.13 \pm 0.08$ for $\sigma_{\text {Irc1 } 1} / \sigma_{\text {Ir(ppy) }}$ ( $1.24 \pm 0.06$ for $\sigma_{\mathrm{IrC} 2} / \sigma_{\operatorname{lr}\left(\text { ppy } 3^{\prime}\right.}$ and $1.54 \pm 0.08$ for $\sigma_{\mathrm{IrC} 3} / \sigma_{\operatorname{lr}(\text { ppy })_{3}}$. For demonstrating the dependence of oxygen sensitivity on the molecular structure of the oxygen-sensitive probes (OSPs), the delocalization of spin populations (DSPs) has been applied for the first time to confirm the collision radius variations of Ir(III) complexes. Remarkable DSPs were found on the TPA, CZ1, and CZ2 moieties with the spin population (percentage of the spin population) of $0.23210(11.61 \%), 0.08862(4.43 \%)$, and 0.13201 $(6.60 \%)$, respectively. And strong linear correlations $\left(R^{2}=0.997\right)$ between the collision radius variations and spin population on TPA and Cz moieties were apparent. The DSPs could be used to describe the dependence of oxygen sensitivity on the molecular structure of the OSPs. For achieving real-time oxygen sensing, the photostability, oxygen sensing performance, and operational stability of IrC1-IrC3 and $\operatorname{Ir}(\mathrm{ppy})_{3}$ immobilized in ethyl cellulose $(\mathrm{EC})$ were investigated. The IrC1-EC film demonstrated outstanding photostability after $60 \mathrm{~min}$ of irradiation and excellent operational stability for continuous oxygen monitoring with no attenuation of the original emission intensity in $4000 \mathrm{~s}$. This study quantified and analyzed the dependence of oxygen sensitivity on the molecular structure of Ir(III) complexes for the first time and illustrated a feasible approach to achieve high-efficiency sensors for real-time monitoring of oxygen.

rsc.li/rsc-advances

Received 25th March 2019 Accepted 12th May 2019

DOI: $10.1039 / c 9 r a 02277$ e
(Winkler titration ${ }^{4}$ and electroanalytical ${ }^{5}$ ), luminescent sensing has become extremely significant in the last two decades due to the overwhelming advantages of its nondestructive characteristics, sensitive luminescence response, excellent reversibility, and versatility of formats (film, fiber, nanoparticle, etc.). ${ }^{6}$ Such type of flexible approach depends on the dynamic (diffusion-controlled) luminescence (phosphorescence or fluorescence) quenching of oxygen-sensitive probes (OSPs). ${ }^{7,8}$ The transition metal complexes are OSPS of choice, including $\operatorname{Ir}(\mathrm{III}),{ }^{9-12} \mathrm{Pt}(\mathrm{II}),{ }^{13,14} \mathrm{Ru}(\mathrm{II})^{15,16}$ complexes, and Pd(II) porphyrins. ${ }^{17,18}$

In general, the oxygen sensitivities of luminescence sensors are roughly proportional to luminescent decay times $(\tau)$ of OSPs. ${ }^{19,20}$ And state of the art luminescent sensors consisted of OSPs possessing luminescent decay times in a wide range of milliseconds to microseconds. ${ }^{21}$ Efforts have been made to design OSPs with long decay times., ${ }^{\mathbf{8 2 2 , 2 3}}$ 
Matrices have been widely used to provide microenvironment for OSPs as encapsulation and regulate the determination range of oxygen. ${ }^{\mathbf{2 4}, 25}$ High oxygen permeability of matrices commonly provided high sensitivity and low limit of detection (LOD). ${ }^{21,26-28}$ Luminescent decay times and oxygen sensitivities of OSPs are sometimes not in direct proportion (short-decayed OSPs with high oxygen sensitivities or vice versa) in the same matrix with the same approach of preparation. Astoundingly, the abnormal phenomena occurred frequently in the related researches. ${ }^{\mathbf{9 , 1 0 , 2 9 - 3 1}}$ For instance, $\operatorname{Ir}(\mathrm{III})$ complexes $\operatorname{Ir}(\mathrm{III})$-a and $\operatorname{Ir}(\mathrm{III})$-b were immobilized in a nano aluminum based matrix (Scheme 1A). In comparison to short-decayed Ir(III)-a, lower oxygen sensitivity of $\operatorname{Ir}(\mathrm{III})$ b with long decay time was showed. ${ }^{9}$ A $t$-butyl substituted Ir(III) complex Ir(III)-d was prepared based on Ir(III)-c (Scheme 1B). The oxygen sensitivity of short-decayed $\operatorname{Ir}$ (III)-c was 6-fold higher than that of long-decayed $\operatorname{Ir}(\mathrm{III})-\mathrm{d} .{ }^{10}$ Zhao et al. conducted a research on the two Pt(II) complexes Pt(II)-a and $\mathrm{Pt}(\mathrm{II})-\mathrm{b}$ with phenylthiazo and thiazo-coumarin ligands, respectively (Scheme 1C). And there was a similar phenomenon that short-decayed Pt(II)-a showed considerably high oxygen sensitivity than that of $\mathrm{Pt}(\mathrm{II})-\mathrm{b} .^{29}$ Coincidentally, parallel results were obtained in our previous reports. ${ }^{32,33}$ Therefore, the molecular structure of OSPs has potential influence which should not be ignored on the oxygen sensitivity.

Carbazole and triphenylamine moieties have drawn a wide range of attention in organic light-emitting diodes (OLEDs) ${ }^{34-38}$ and dye-sensitized solar cells (DSSCs) due to intriguing properties of high light-to-electrical energy conversion efficiencies, strong electron-donating nature and good hole-transporting abilities. ${ }^{39-41}$ Herein, we report a systematic quantification and analysis of the dependence of oxygen sensitivity on the molecular structure of OSPs by the modification of traditional $\operatorname{Ir}(\mathrm{III})$ complex $\operatorname{Ir}(\mathrm{ppy})_{3}$ with 4- (diphenylamino)phenyl (TPA), 4-(9H-carbazol-9-yl)phenyl (Cz1), and 9-phenyl-9H-carbazol-3-yl (Cz2) moieties. Molecular structures and synthetic routes of IrC1, IrC2, IrC3 and $\operatorname{Ir}(\mathrm{ppy})_{3}$ were illustrated in Scheme 2 .

\section{Experimental}

\subsection{Materials and methods}

The corresponding boronic acids, $\mathrm{Pd}(\mathrm{OAc})_{2}, \mathrm{Pd}\left(\mathrm{PPh}_{3}\right)_{4}$, and $\mathrm{IrCl}_{3} \cdot 3 \mathrm{H}_{2} \mathrm{O}$ were purchased from Alfa Aesar. Other purified reagents were purchased from Greagent. ${ }^{1} \mathrm{H}$ NMR and ${ }^{13} \mathrm{C}$ NMR spectra were measured on a BRUKER AVANCE III HD spectrometer $(400 \mathrm{MHz})$. High-resolution MS were measured with a 1290/6224 HPLC/MS spectrometer. ${ }^{20}$ The UV/Vis spectrometer (cary 5000) and fluorescence spectrophotometer (cary eclipse G9800A) of Agilent Technology were used to record absorption spectra and emission spectra. The excitedstate lifetime curves were recorded on LP920 Laser Flash photolysis apparatus of Edinburgh Instruments Ltd (excitation wavelength: $355 \mathrm{~nm}$, pulse width: $6.4 \mathrm{~ns}$, frequency: $3 \mathrm{~Hz}$, single pulse energy: $1 \mathrm{~mJ}$ ). The 2273 electrochemical workstation of Princeton Applied Research was used for the cyclic voltammetry tests.

\subsection{Synthesis section}

Synthetic procedure of ligand L1, L2, and L3. $0.5 \mathrm{mmol}$ of 2(3-bromophenyl)pyridine (116.5 $\mathrm{mg}), 0.75 \mathrm{mmol}$ of corresponding boronic acid, 2.0 equiv. of $\mathrm{K}_{2} \mathrm{CO}_{3}(138.0 \mathrm{mg})$, $\mathrm{Pd}\left(\mathrm{PPh}_{3}\right)_{4}(5.0 \mathrm{~mol} \%, 0.025 \mathrm{mmol}, 28.9 \mathrm{mg})$, and $\mathrm{THF} / \mathrm{H}_{2} \mathrm{O}$ $(10 \mathrm{~mL} / 6 \mathrm{~mL})$ were mixed and stirred at $85{ }^{\circ} \mathrm{C}$ in $\mathrm{N}_{2}$ for 6 hours. Then $15 \mathrm{~mL}$ brine was added into the mixture. Then the mixture was extracted with ethyl acetate (EA, $4 \times 10 \mathrm{~mL}$ ). The organic phase was condensed and the corresponding product was isolated by column chromatography using petroleum ether/EA (50: 1 for L1, $20: 1$ for $\mathbf{L 2}$, and L3, v : v).

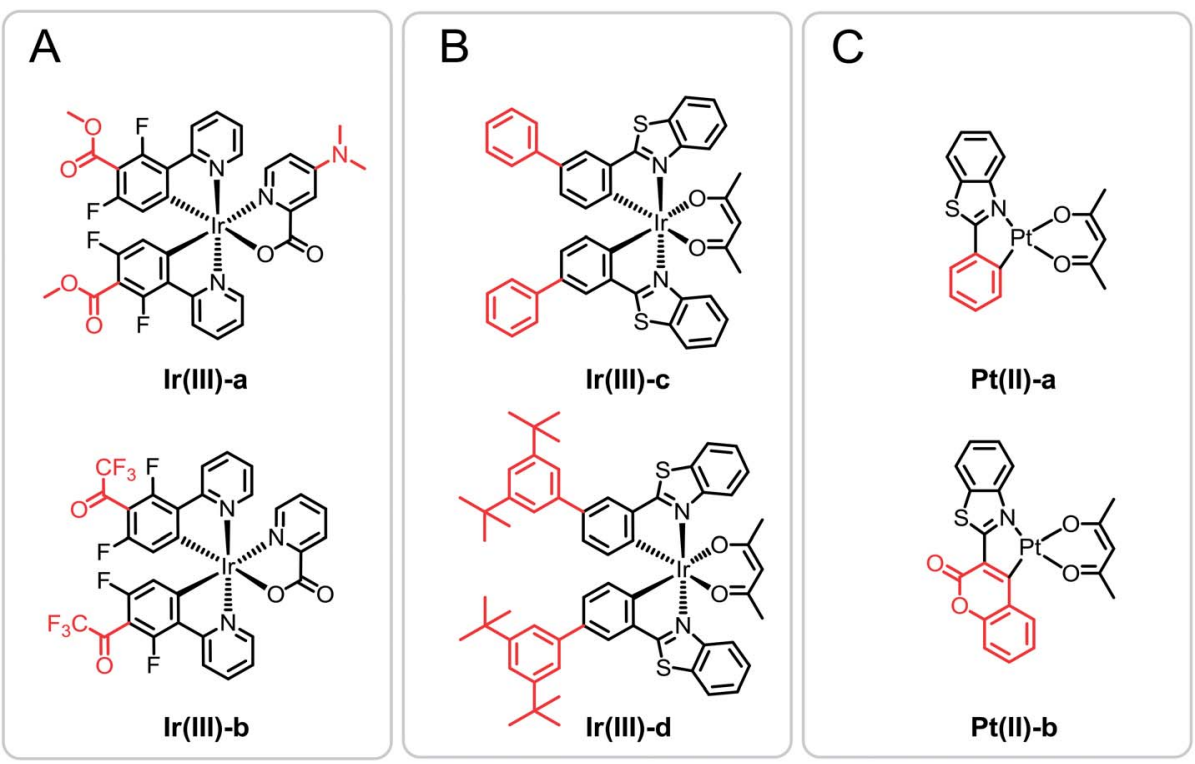

Scheme 1 Chemical structures of referenced Ir(III) and Pt(II) OSPs. Structure variations is shown with red. 

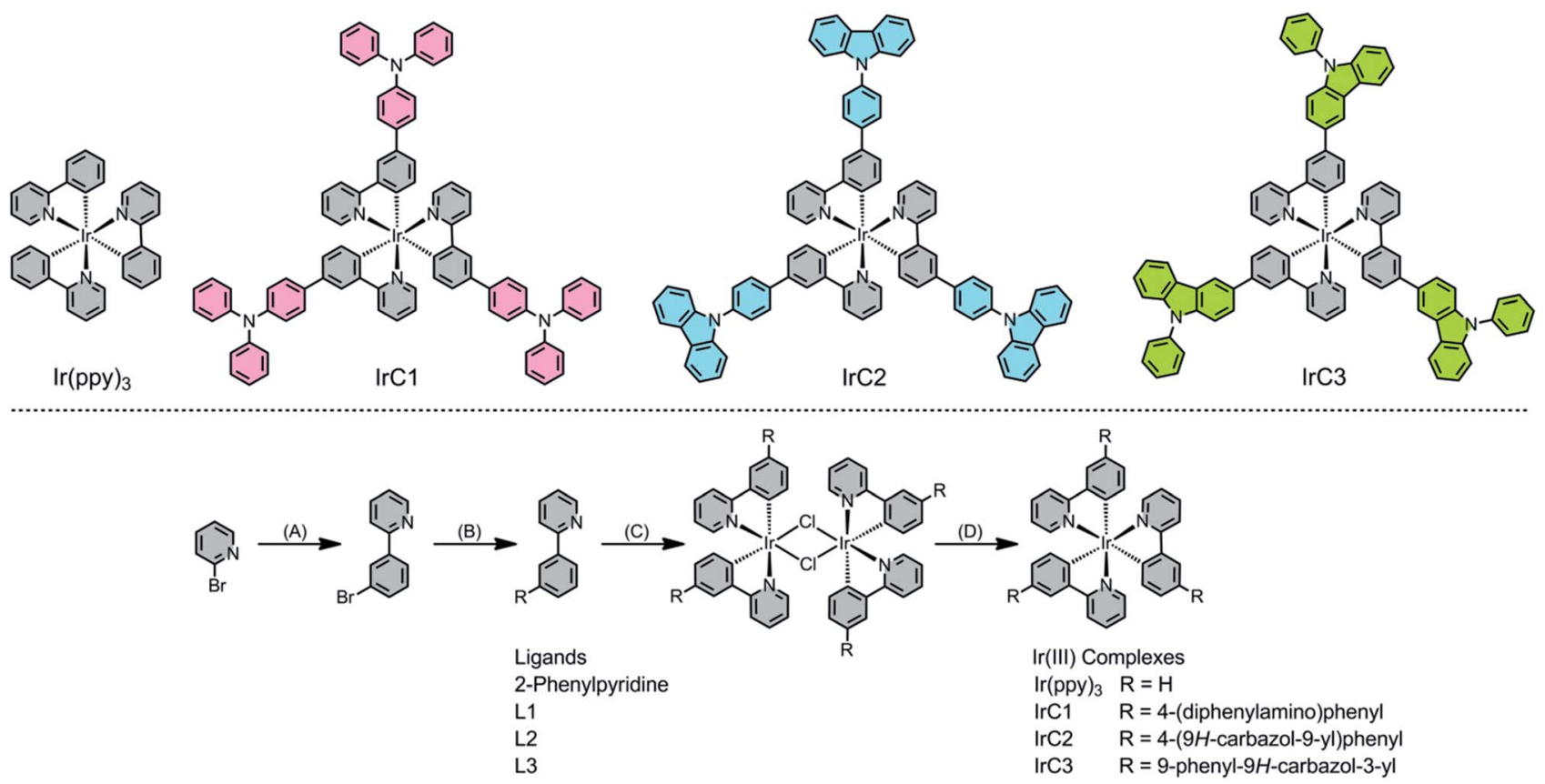

Scheme 2 Molecular structures and synthetic routes of ligands and Ir(III) complexes. (A) (3-Bromophenyl)boronic acid, $\mathrm{Pd}\left(\mathrm{OAC}_{2}, \mathrm{~K}_{2} \mathrm{CO}_{3}\right.$, $\mathrm{C}_{2} \mathrm{H}_{5} \mathrm{OH} / \mathrm{H}_{2} \mathrm{O}$ (3: $\left.1, \mathrm{v}: \mathrm{v}\right), 85^{\circ} \mathrm{C}, 3$ hours. (B) $\mathrm{RB}(\mathrm{OH})_{2}, \mathrm{Pd}\left(\mathrm{PPh}_{3}\right)_{4}, \mathrm{~K}_{2} \mathrm{CO}_{3}, \mathrm{THF}: \mathrm{H}_{2} \mathrm{O} 5: 3$ (v:v), $80{ }^{\circ} \mathrm{C}$ in $\mathrm{N}_{2}, 6$ hours. (C) IrCl $3 \cdot 3 \mathrm{H}_{2} \mathrm{O}, \mathrm{C}_{2} \mathrm{H}_{5}-$ $\mathrm{OCH}_{2} \mathrm{CH}_{2} \mathrm{OH} / \mathrm{H}_{2} \mathrm{O}$ (3: $\left.1, \mathrm{v}: \mathrm{v}\right), 110{ }^{\circ} \mathrm{C}$ in $\mathrm{N}_{2}, 36$ hours. (D) The corresponding ligands, $\mathrm{Na}_{2} \mathrm{CO}_{3}$, glycerol, $200{ }^{\circ} \mathrm{C}$ in $\mathrm{N}_{2}$, 48 hours.

L1, $N, N$-Diphenyl-3'-(pyridin-2-yl)-[1,1'-biphenyl]-4-amine. Yield: $82.2 \%$; white solid. ${ }^{1} \mathrm{H}$ NMR $\left(400 \mathrm{MHz} \mathrm{CDCl}_{3}\right) \delta 8.72$ (d, 1H), $8.22(\mathrm{~d}, 1 \mathrm{H}), 7.93(\mathrm{~s}, 1 \mathrm{H}), 7.79(\mathrm{~d}, 2 \mathrm{H}), 7.63(\mathrm{~s}, 1 \mathrm{H})$, 7.60-7.50 (m, 3H), 7.27 (s, 5H), 7.17 (s, 3H), 7.15 (s, 3H), 7.05 $(\mathrm{d}, 2 \mathrm{H}){ }^{42}$

L2, 9-(3'-(Pyridin-2-yl)-[1,1'-biphenyl]-4-yl)-9H-carbazole. Yield: 79.1\%; white solid. ${ }^{1} \mathrm{H}$ NMR (400 $\left.\mathrm{MHz} \mathrm{CDCl}_{3}\right) \delta 8.78$ $(\mathrm{d}, 1 \mathrm{H}), 8.38(\mathrm{~s}, 1 \mathrm{H}), 8.16(\mathrm{~d}, 2 \mathrm{H}), 8.03(\mathrm{~d}, 1 \mathrm{H}), 7.93(\mathrm{~d}, 2 \mathrm{H})$, $7.88(\mathrm{~s}, 2 \mathrm{H}), 7.78(\mathrm{~d}, 1 \mathrm{H}), 7.70-7.60(\mathrm{~m}, 3 \mathrm{H}), 7.52-7.40(\mathrm{~m}$, $4 \mathrm{H}), 7.31(\mathrm{t}, 3 \mathrm{H}) .{ }^{13} \mathrm{C}$ NMR (101 $\left.\mathrm{MHz} \mathrm{CDCl}_{3}\right) \delta$ 157.1, 149.6, $140.9,140.8$, 140.1, 139.8, 137.1, 137.0, 129.4, 128.7, 127.8, $127.3,126.2$, 125.9, 123.4, 122.4, 120.8, 120.3, 119.9, 109.8 . HRMS (ESI): calc. for $\mathrm{C}_{29} \mathrm{H}_{21} \mathrm{~N}_{2}: 397.1705[\mathrm{M}+\mathrm{H}]^{+}$. Found: $397.1702[\mathrm{M}+\mathrm{H}]^{+}$.

L3, 9-Phenyl-3-(3-(pyridin-2-yl)phenyl)-9H-carbazole. Yield: 77.2\%; white solid. ${ }^{1} \mathrm{H}$ NMR (400 $\left.\mathrm{MHz} \mathrm{CDCl}_{3}\right) \delta 8.77$ $(\mathrm{d}, 1 \mathrm{H}), 8.46(\mathrm{~s}, 1 \mathrm{H}), 8.37(\mathrm{~s}, 1 \mathrm{H}), 8.22(\mathrm{~d}, 1 \mathrm{H}), 7.96(\mathrm{~d}, 1 \mathrm{H})$, $7.85(\mathrm{t}, 2 \mathrm{H}), 7.81-7.72(\mathrm{~m}, 2 \mathrm{H}), 7.66-7.56(\mathrm{~m}, 5 \mathrm{H}), 7.52-7.46$ $(\mathrm{m}, 2 \mathrm{H}), 7.43(\mathrm{~d}, 2 \mathrm{H}), 7.31(\mathrm{dt}, 2 \mathrm{H}) .{ }^{13} \mathrm{C}$ NMR $(101 \mathrm{MHz}$, $\left.\mathrm{CDCl}_{3}\right) \delta 157.6,149.6,142.6,141.3,140.5,139.8,137.6,136.9$, 133.2, 129.9, 129.2, 128.0, 127.5, 127.1, 126.1, 126.0, 125.6, 125.2, 123.9, 123.5, 122.2, 120.9, 120.5, 120.1, 119.0, 110.0, 109.9. HRMS (ESI): calc. for $\mathrm{C}_{29} \mathrm{H}_{21} \mathrm{~N}_{2}$ : $397.1705[\mathrm{M}+\mathrm{H}]^{+}$. Found: $397.1703[\mathrm{M}+\mathrm{H}]^{+}$.

Synthetic procedure of Ir(III) complexes IrC1, IrC2, and IrC3. The corresponding ligand $0.8 \mathrm{mmol}$ (L1 $318.4 \mathrm{mg}, \mathbf{L 2}$ $316.8 \mathrm{mg}$, L3 $316.8 \mathrm{mg}$, respectively) was reacted with 0.6 equiv. of $\mathrm{IrCl}_{3} \cdot 3 \mathrm{H}_{2} \mathrm{O}(0.48 \mathrm{mmol}, 169 \mathrm{mg})$ in $\mathrm{C}_{2} \mathrm{H}_{5} \mathrm{OCH}_{2}$ $\mathrm{CH}_{2} \mathrm{OH} / \mathrm{H}_{2} \mathrm{O}(12 \mathrm{~mL} / 4 \mathrm{~mL})$ at $110{ }^{\circ} \mathrm{C}$ for $36 \mathrm{~h}$ under $\mathrm{N}_{2}$. The solution was condensed to afford a powder of iridium chloride-bridged dimer. Without purification, the dimer was reacted with 1.2 equiv. ( $0.48 \mathrm{mmol}$ ) corresponding ligand (L1 $191 \mathrm{mg}$, L2 $190 \mathrm{mg}$, L3 $190 \mathrm{mg}$, respectively) and 5 equiv. of $\mathrm{Na}_{2} \mathrm{CO}_{3}$ (4 mmol, $424 \mathrm{mg}$ ) in $25 \mathrm{~mL}$ glycerol at $200{ }^{\circ} \mathrm{C}$ for 2 days under $\mathrm{N}_{2}$. Upon cooling to room temperature, the mixture was poured into water and extracted with $\mathrm{CH}_{2} \mathrm{Cl}_{2}(3$ $\times 25 \mathrm{~mL}$ ). The organic phase was condensed and the corresponding product was isolated by column chromatography using dichloromethane. ${ }^{33}$

IrC1: yield: 77.4\%; yellow powder. ${ }^{1} \mathrm{H}$ NMR $(400 \mathrm{MHz}$, $\left.\mathrm{CDCl}_{3}\right) \delta 7.96(\mathrm{~s}, 3 \mathrm{H}), 7.86(\mathrm{~s}, 3 \mathrm{H}), 7.64-7.57(\mathrm{~m}, 6 \mathrm{H}), 7.50(\mathrm{~s}$, $3 \mathrm{H}), 7.48(\mathrm{~d}, 3 \mathrm{H}), 7.23(\mathrm{~s}, 6 \mathrm{H}), 7.20(\mathrm{~s}, 3 \mathrm{H}), 7.12(\mathrm{~s}, 12 \mathrm{H}), 7.10-$ $7.02(\mathrm{~m}, 12 \mathrm{H}), 7.00(\mathrm{~s}, 3 \mathrm{H}), 6.99-6.94(\mathrm{~m}, 6 \mathrm{H}), 6.91-6.86(\mathrm{~m}$, $3 \mathrm{H}) .{ }^{13} \mathrm{C} \mathrm{NMR}\left(101 \mathrm{MHz}, \mathrm{CDCl}_{3}\right) \delta 169.7,167.6,146.9,143.2$, 142.9, 139.3, 136.8, 136.4, 136.1, 131.2, 130.1, 129.1, 128.4, 125.3, 123.9, 123.1, 121.2, 121.0, 118.5. HRMS (ESI) for $\mathrm{C}_{87} \mathrm{H}_{64} \mathrm{IrN}_{6}$, calc.: $1385.4822[\mathrm{M}+\mathrm{H}]^{+}$. Found: $1385.4820[\mathrm{M}+$ $\mathrm{H}]^{+}{ }^{42}$

IrC2: yield: 70.4\%; yellow powder. ${ }^{1} \mathrm{H}$ NMR $(400 \mathrm{MHz}$, $\left.\mathrm{CDCl}_{3}\right) \delta 8.14(\mathrm{t}, 9 \mathrm{H}), 8.05(\mathrm{t}, 6 \mathrm{H}), 7.88(\mathrm{~d}, 6 \mathrm{H}), 7.68(\mathrm{~d}, 6 \mathrm{H})$, 7.63-7.57 (m, 6H), 7.49-7.39 (t, 18H), 7.30 (d, 6H). ${ }^{13} \mathrm{C}$ NMR $\left(101 \mathrm{MHz}, \mathrm{CDCl}_{3}\right) \delta 166.2,150.2,141.3,141.1,138.6,137.8$, $135.4,135.0,129.7,129.2,128.4$, 127.9, 127.0, 125.3, 122.4, 121.3, 120.2 119.6, 119.1, 108.4. HRMS (ESI) for $\mathrm{C}_{87} \mathrm{H}_{58} \mathrm{IrN}_{6}$, calc.: 1379.4352 $[\mathrm{M}+\mathrm{H}]^{+}$. Found: $1379.4347[\mathrm{M}+\mathrm{H}]^{+}$.

IrC3: yield: $75.2 \%$; yellow powder. ${ }^{1} \mathrm{H}$ NMR $(400 \mathrm{MHz}$, $\left.\mathrm{CDCl}_{3}\right) \delta 8.39(\mathrm{~s}, 3 \mathrm{H}), 8.17(\mathrm{~d}, 6 \mathrm{H}), 8.10(\mathrm{~d}, 6 \mathrm{H}), 8.05(\mathrm{~s}, 6 \mathrm{H})$, 7.68 (d, 6H), $7.60(\mathrm{~d}, 12 \mathrm{H}), 7.47-7.39(\mathrm{~m}, 12 \mathrm{H}), 7.30(\mathrm{~d}, 6 \mathrm{H})$. ${ }^{13} \mathrm{C} \mathrm{NMR}\left(101 \mathrm{MHz}, \mathrm{CDCl}_{3}\right) \delta 167.5,150.8,143.3,142.9,140.1$, $138.8,136.7,135.4,134.4,133.3$, 130.0, 128.8, 127.7, 126.3, $125.9,124.8,124.2,122.7,122.5,121.8,121.3,119.3,118.8$, 

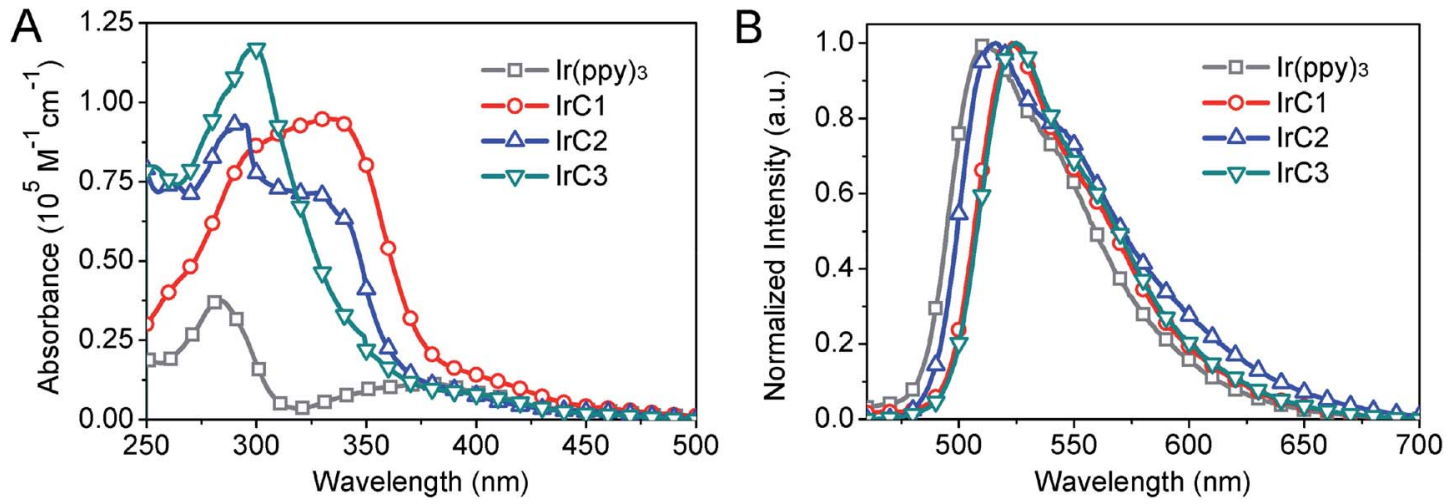

Fig. 1 (A) UV-vis spectra and (B) luminescent spectra of $\operatorname{IrC1} 1-\operatorname{IrC} 3$ and $\operatorname{Ir}(\mathrm{ppy})_{3}$.

Table 1 Photophysical parameter of $\operatorname{IrC1}-\operatorname{IrC} 3$ and $\operatorname{Ir}(\mathrm{ppy})_{3}$

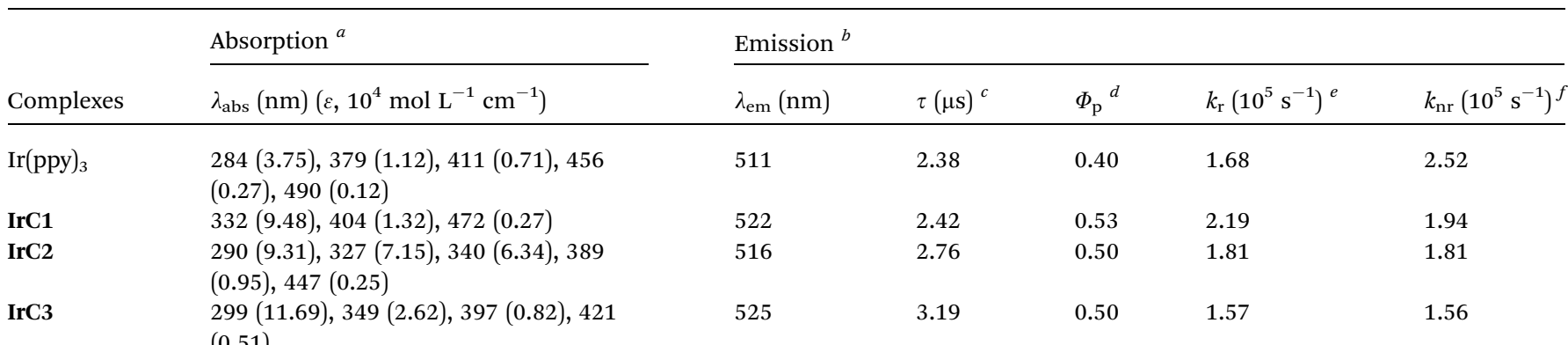

${ }^{a}$ In THF at a concentration of $10^{-5} \mathrm{~mol} \mathrm{~L}^{-1} \cdot{ }^{b}$ In degassed THF. ${ }^{c} \lambda_{\mathrm{ex}}=355 \mathrm{~nm} \cdot{ }^{d}$ Relative to $\operatorname{Ir}(\mathrm{ppy})_{2}(\mathrm{acac})\left(\Phi_{\mathrm{p}}=0.34\right) \cdot{ }^{e} k_{\mathrm{r}}=\Phi_{\mathrm{p}} / \tau \cdot{ }^{f} k_{\mathrm{nr}}=(1 / \tau)-k_{\mathrm{r}}$.

117.7, 117.1, 108.8, 108.7. HRMS (ESI) for $\mathrm{C}_{87} \mathrm{H}_{58} \mathrm{IrN}_{6}$, calc.: 1379.4352 $[\mathrm{M}+\mathrm{H}]^{+}$. Found: $1379.4342[\mathrm{M}+\mathrm{H}]^{+}$.

\section{Result and discussion}

\subsection{Photophysical properties}

UV-visible absorption of IrC1-IrC3 and $\operatorname{Ir}(\mathrm{ppy})_{3}$ have been measured in THF at room temperature (Fig. 1A and Table 1). Strong bands up to $310 \mathrm{~nm}$ attributed to $\pi-\pi *$ transitions of intraligands. Bands of lower-energy absorption at $350 \mathrm{~nm}$ were assigned to metal-to-ligand charge transfer transitions (MLCT). The spin-forbidden transitions of triplet states ascribed to weak bands at $400 \mathrm{~nm}$ with absorption coefficients of $2000 \mathrm{M}^{-1} \mathrm{~cm}^{-1}$. The similar band positions and significant differences of absorption coefficients of IrC1-IrC3 and $\operatorname{Ir}(\mathrm{ppy})_{3}$ were observed. In comparison with $\operatorname{Ir}(\mathrm{ppy})_{3}$, intensity of the first band at $280 \mathrm{~nm}$ and the second band at $350 \mathrm{~nm}$ of IrC1-IrC3 were enhanced which was attributed to $\pi-\pi *$ transition and MLCT of intraligands. It is probably due to the enhanced delocalization of the excited electron on TPA, Cz1, and Cz2 moieties which was confirmed by theoretical calculations (Fig. 2). ${ }^{\mathbf{4 3}}$

The emission maxima were in region from 511 to $525 \mathrm{~nm}$ which was excited in the MLCT bands (Fig. 1B and Table 1). In comparison to $\operatorname{Ir}(\mathrm{ppy})_{3}(511 \mathrm{~nm})$, introduction of TPA and $\mathrm{Cz}$ moieties showed bathochromic shift of emission maxima of IrC1 $(522 \mathrm{~nm}), \operatorname{IrC2}(516 \mathrm{~nm})$, and IrC3 $(525 \mathrm{~nm})$. The emission maxima of IrC1 was shifted to a longer wavelength by TPA moieties. The phosphorescence quantum yields $\left(\Phi_{\mathrm{p}}\right)$ of IrC1 (0.53), IrC2 (0.50), IrC3 (0.50) were enhanced compared to $\operatorname{Ir}(\mathrm{ppy})_{3}(0.40)$ (Table 1$)$. The luminescent decay times $(\tau)$ were in the sequence of IrC3 $(3.19 \pm 0.02 \mu \mathrm{s})>$ IrC2 $(2.76 \pm 0.01 \mu \mathrm{s})>\operatorname{IrC1}(2.42 \pm 0.03 \mu \mathrm{s})>\operatorname{Ir}(\mathrm{ppy})_{3}(2.38 \pm 0.02$ $\mu \mathrm{s})$. The $\tau$ in microseconds inferred that the emissions were phosphorescent (Table 1 and Fig. S1, see ESI $\dagger$ ). ${ }^{44}$ Radiative $\left(k_{\mathrm{r}}\right)$ and nonradiative $\left(k_{\mathrm{nr}}\right)$ decay rates were calculated by $\Phi_{\mathrm{p}}$ and $\tau$. And the radiative lifetimes $\tau_{\mathrm{rad}}\left(1 / k_{\mathrm{r}}\right)$ for IrC1-IrC3 and $\operatorname{Ir}(\text { ppy })_{3}$ were $4.57 \mu \mathrm{s}, 5.52 \mu \mathrm{s}, 6.40 \mu \mathrm{s}$, and $5.95 \mu \mathrm{s}$, respectively (Table 1). Compared to IrC1, the extended $\tau_{\text {rad }}$ of IrC2 and IrC3 was possibly attributed to enhanced conjugation effects which was caused by $\mathrm{Cz}$ moieties. ${ }^{45}$ The changes in emission color were quantified with CIE coordinates of $(0.2750,0.6268)$ for $\operatorname{Ir}(\mathrm{ppy})_{3},(0.3164,0.6341)$ for IrC1, $(0.3286,0.6090)$ for IrC2, and $(0.3242,0.6332)$ for IrC3 (Fig. S2, see ESI $\dagger$ ).

\subsection{Electrochemical properties}

The electrochemical behaviors of IrC1-IrC3 and $\operatorname{Ir}(\mathrm{ppy})_{3}$ were studied by cyclic voltammetry (Table 2). The introduction of TPA moieties leaded to more negative oxidation potential $(0.78 \mathrm{~V})$ and higher HOMO energy level $(-5.18 \mathrm{eV})$ of IrC1. And the introduction of $\mathrm{Cz}$ moieties showed more obvious cathodic shifts of oxidation potentials of IrC2 $(0.72 \mathrm{~V})$ and IrC3 $(0.67 \mathrm{~V})$ in comparison with $\operatorname{Ir}(\mathrm{ppy})_{3}(0.84 \mathrm{~V}) . \operatorname{Ir}(\mathrm{ppy})_{3}$ 


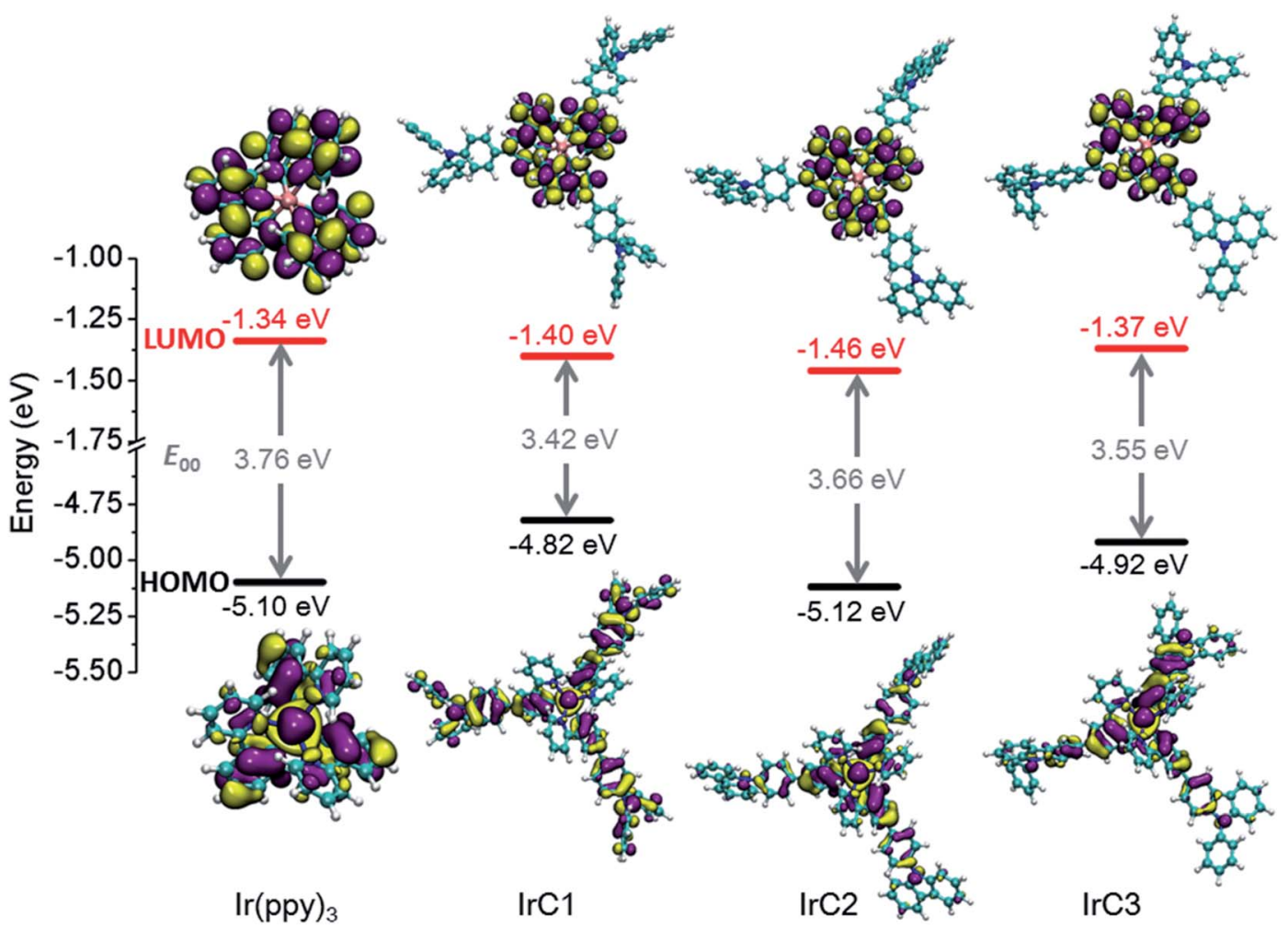

Fig. 2 Electron density isosurfaces (0.02 a.u.) of frontier molecular orbitals of Ir(III) complexes.

Table 2 Electrochemical data and frontier orbital energy levels of $\operatorname{IrC} 1-\operatorname{IrC} 3$ and $\operatorname{Ir}(\mathrm{ppy})_{3}$

\begin{tabular}{|c|c|c|c|c|c|c|}
\hline $\begin{array}{l}\operatorname{Ir}(\mathrm{III}) \\
\text { complexes }\end{array}$ & $E_{\mathrm{ox}}^{\text {on }} \operatorname{set} a(\mathrm{~V})$ & $E_{\text {номо }}{ }^{b}(\mathrm{eV})$ & $E_{\text {LUMO }}{ }^{c}(\mathrm{eV})$ & $\lambda_{\text {edge }}{ }^{d}(\mathrm{~nm})$ & $E_{00}{ }^{e}(\mathrm{eV})$ & $E_{\mathrm{ox}}^{*}(\mathrm{~V})^{f}$ \\
\hline $\operatorname{Ir}(\text { ppy })_{3}$ & 0.84 & -5.24 & -2.96 & 544 & 2.28 & -1.44 \\
\hline IrC2 & 0.72 & -5.12 & -2.89 & 556 & 2.23 & -1.51 \\
\hline IrC3 & 0.67 & -5.07 & -2.96 & 587 & 2.11 & -1.44 \\
\hline
\end{tabular}

${ }^{a}$ Onset oxidation potential. $0.1 \mathrm{~mol} \mathrm{~L}^{-1}\left[\mathrm{Bu}_{4} \mathrm{~N}\right] \mathrm{PF}_{6}$ was dissolved in degassed THF. The standard electrode was SCE. ${ }^{b}$ HOMO energy level, $E_{\mathrm{HOMO}}$ $(\mathrm{eV})=-e\left(4.4+E_{\mathrm{ox}}^{\mathrm{on}}{ }^{\mathrm{set}}\right) .{ }^{c}$ LUMO energy level, $E_{\mathrm{LUMO}}=E_{\mathrm{HOMO}}+E_{00} \cdot{ }^{d}$ Absorption edge data, which were measured from solid UV-vis spectra. ${ }^{e}$ Zerozero emission energy level. $E_{00}=1240 / \lambda_{\text {edge. }}{ }^{f}$ Oxidation potential of excited state: $E_{\mathrm{ox}}^{*}=E_{\mathrm{ox}}^{\mathrm{on}}{ }^{\circ e t}-E_{00} \cdot{ }^{46}$

and IrC1 demonstrated quasi-reversible reduction waves, which exhibited electrochemical stability and relative difficulty of oxidation. While IrC2 and IrC3 showed irreversible reduction waves (Fig. S3, see ESI†). Therefore all the HOMO energy levels were calculated by the onset oxidation potentials $\left(E_{\text {ox }}^{\text {on set }}\right.$ (Table 2$)$. The data of zero-zero emission energy levels $\left(E_{00}\right)$ were calculated by the absorption edge data $\left(\lambda_{\text {edge }}\right)$ of solid UV-vis spectra (Fig. S4, see ESI $\dagger$ ). The data of $E_{00}$ with order of $\operatorname{Ir}(\text { ppy })_{3}(2.28 \mathrm{eV})>\operatorname{IrC2}(2.23 \mathrm{eV})>\operatorname{IrC1}(2.16 \mathrm{eV})>$ IrC3 $(2.11 \mathrm{eV})$ were in accordance with the order of emission maxima in Fig. $1 \mathrm{~B}$.

\subsection{Theoretical calculations}

Density functional theory (DFT) calculations (B3LYP level, mixed basis sets of $6-31 G^{*}$ and LanL2DZ) based on the polarizable continuum model (PCM $=\mathrm{THF}$ ) were applied to optimize the ground-state geometries of $\operatorname{Ir}\left(\right.$ III) complexes $^{20}$ (Fig. 2). TPA moieties of IrC1 take no-co-planar geometry. Contrastively, large $\pi$-conjugation were presented on $\mathrm{Cz} 1$ and Cz2 moieties of IrC2 and IrC3 just as expected. It was clear that 2-phenylpyridine moieties significantly contributed the LUMOs of IrC1-IrC3 and $\operatorname{Ir}(\mathrm{ppy})_{3}$. And none of electron population on $\operatorname{Ir}(\mathrm{III})$ atom, TPA, and $\mathrm{Cz}$ moieties of LUMOs. $\operatorname{Ir}(\mathrm{III})$ atoms and benzene rings of 2-phenylpyridines mainly contributed the HOMOs, while pyridine rings slightly contributed the HOMOs. The electron delocalization was increased on the propeller structures of IrC1. While the $\pi$ conjugation reduced the electron delocalization on $\mathrm{Cz}$ moieties of HOMOs of IrC2 and IrC3. These frontier molecular orbital energies in Fig. 2 and Table 2 were not over-interpreted 
because of acceptable differences between experimental and calculated data. ${ }^{47}$

\subsection{Luminescence sensing of molecular oxygen}

The Stern-Volmer relationship (eqn (1)) described the diffusion-controlled luminescent quenching process between OSPs and oxygen. $I$ and $\tau$ are emission intensities and luminescent decay times of OSPs, respectively. $I_{0}$ and $\tau_{0}$ are corresponding values in the absence of oxygen. $k_{\mathrm{q}}$ means the bimolecular quenching constant and $\left[\mathrm{O}_{2}\right]$ expresses the molar concentration of molecular oxygen. The Stern-Volmer plots (SVPs) are gotten with slopes of $k_{\mathrm{q}} \tau_{0}$ by linear fitting.

$$
\frac{I_{0}}{I}=\frac{\tau_{0}}{\tau}=1+k_{\mathrm{q}} \tau_{0}\left[\mathrm{O}_{2}\right]
$$

In order to drastically eliminate the influence of heterogeneity and accurately characterize original oxygen sensitivities, purified THF was used to disperse Ir(III) complexes. The emission intensities of IrC1-IrC3 and $\operatorname{Ir}(\mathrm{ppy})_{3}$ were obviously weaken with incremental concentration of $\mathrm{O}_{2}$ in the air volume of $0-100 \%$. $6.8 \%$ of oxygen concentration could quench over $81 \%$ of original emission intensities. Noteworthily, above $90 \%$ of original emission intensity of IrC1 was quenched with $6.8 \%$ of oxygen which demonstrated high oxygen sensitivity (Fig. 3).

The two-site model ${ }^{48}$ was applied to fit the SVPs (eqn (2)). Where $f_{1}$ and $f_{2}$ are the quenchable and unquenchable fractions, respectively. And $K_{\mathrm{Sv} 1}$ and $K_{\mathrm{SV} 2}$ are quenching rate constants for corresponding fractions. $f_{1}+f_{2}=1$. $p_{\mathrm{O}_{2}}$ means oxygen partial pressure. Oxygen sensitivities of OSPs are illustrated by the weighted constant $K_{\mathrm{SV}}^{\mathrm{app}}\left(K_{\mathrm{SV}}^{\mathrm{app}}=f_{1} K_{\mathrm{SV} 1}+f_{2} K_{\mathrm{SV} 2}\right)$.

$$
\frac{I}{I_{0}}=\frac{\tau}{\tau_{0}}=\frac{f_{1}}{1+K_{\mathrm{SV} 1} p_{\mathrm{O}_{2}}}+\frac{f_{2}}{1+K_{\mathrm{SV} 2} p_{\mathrm{O}_{2}}}
$$

Decline ratios of emission intensity of IrC1-IrC3 and $\operatorname{Ir}(\mathrm{ppy})_{3}$ were fitted by the two-site model in Fig. 4 and Table S1 (see ESI $\dagger$ ). The $I_{0} / I_{100}$ of IrC1-IrC3 and $\operatorname{Ir}(\mathrm{ppy})_{3}$ were 168.6, 115.1, 158.1, and 79.4, respectively. And $K_{\mathrm{SV}}^{\mathrm{app}}$ of IrC1-IrC3 and $\operatorname{Ir}(\mathrm{ppy})_{3}$ were $202.2 \mathrm{bar}^{-1}, 144.1 \mathrm{bar}^{-1}, 181.1 \mathrm{bar}^{-1}$, and $119.6 \mathrm{bar}^{-1}$. IrC1 demonstrated the highest oxygen sensitivity than others. The oxygen sensitivities were in the order of IrC1 $>$ IrC3 $>$ IrC2 $>\operatorname{Ir}(\text { ppy })_{3}$. Hence, introducing TPA and $\mathrm{Cz}$ moieties distinctly made Ir(III) complexes more sensitive to oxygen. Noticeably, large quenchable portions $\left(f_{1}\right)$ of IrC1 (0.998), IrC2 (0.999), and IrC3 (0.999) were improved compared with that of $\operatorname{Ir}(\mathrm{ppy})_{3}(0.985)$, which demonstrated considerable linearity of SVPs and more homogeneous

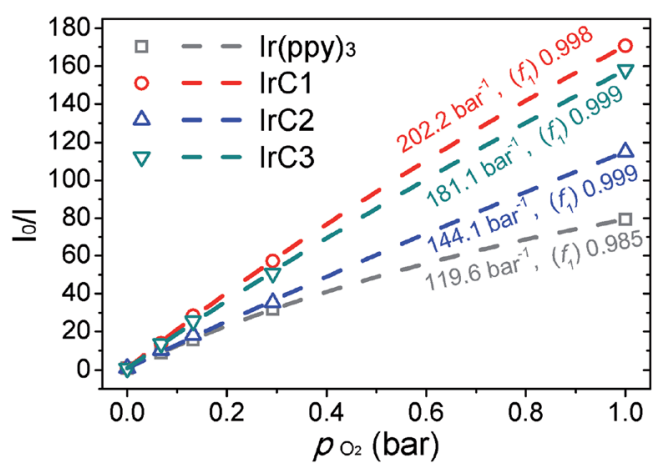

Fig. 4 SVPs for $\operatorname{IrC1} 1-\operatorname{IrC} 3$ and $\operatorname{Ir}(\mathrm{ppy})_{3}$ in THF (fitted by two-site model).
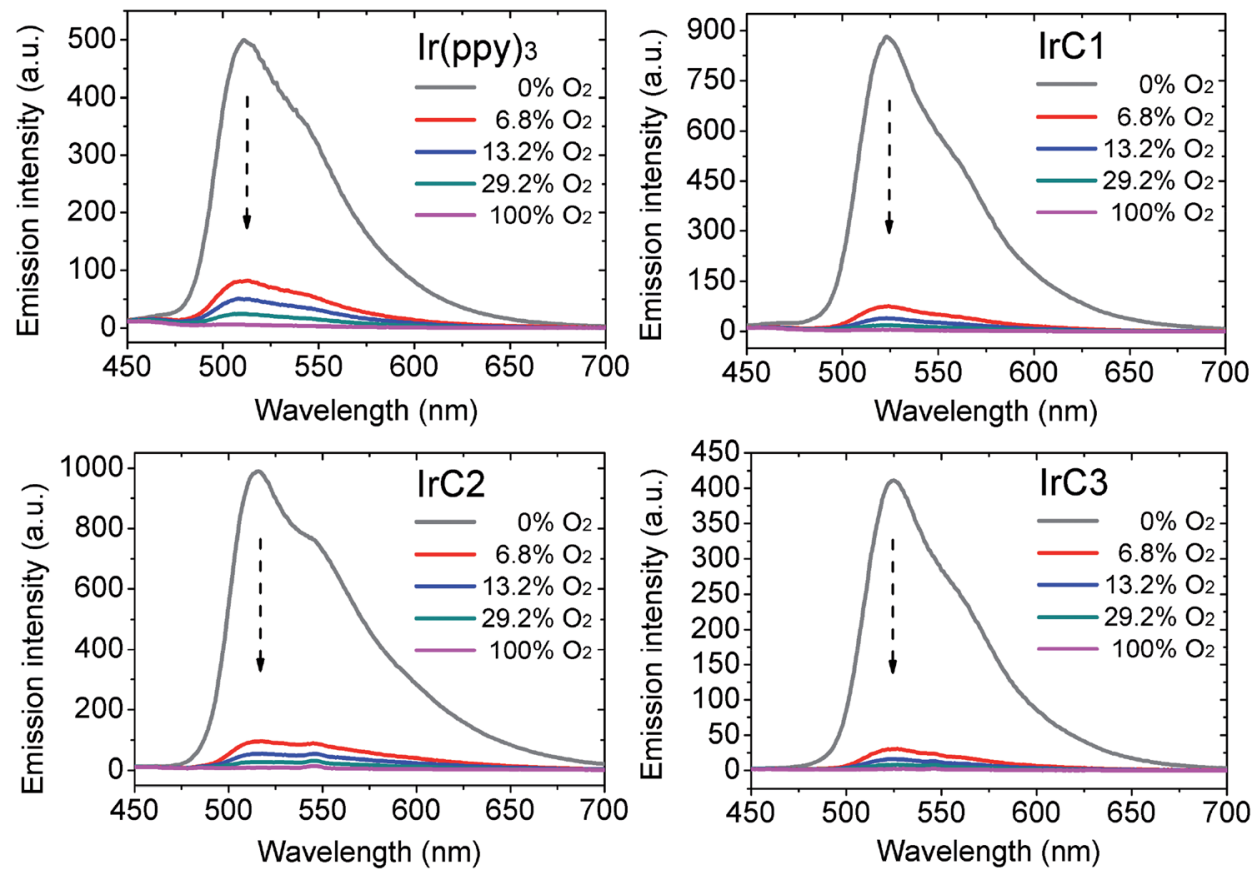

Fig. 3 Dependence of luminescent spectra of $\operatorname{Ir}(\mathrm{II})$ complexes in $\mathrm{THF}\left(10^{-5} \mathrm{~mol} \mathrm{~L}^{-1}\right)$ of $0-100 \% \mathrm{O}_{2}$. 
microenvironment. The limit of detections (LODs) of IrC1IrC3 and $\operatorname{Ir}(\mathrm{ppy})_{3}$ in THF were 0.27 mbar, 0.40 mbar, 0.28 mbar, and 0.43 mbar, respectively (see ESI $\dagger$ ).

\subsection{Variations of the collision radius}

Winnik et al. reported the fundamental expression of luminescent oxygen sensing (eqn (3)). ${ }^{7}$ In eqn (3), $P_{\mathrm{O}_{2}}$ means oxygen permeability of solvents or matrices. $N_{\mathrm{A}}$ means the constant of Avogadro. $\alpha$ expresses the constant of luminescent quenching probability. $\sigma$ represents the collision radii of OSPs to molecular oxygen. In eqn (3), $P_{\mathrm{O}_{2}}$ describes the dependence of oxygen sensitivity on matrices. And high values of $P_{\mathrm{O}_{2}}$ caused high oxygen sensitivities of OSPs. ${ }^{26} \tau_{0}$ illustrates the dependence of oxygen sensitivity on the photophysical properties of OSPs. Long-lived $\tau_{0}$ leaded to high oxygen sensitivities of OSPs. ${ }^{19,21}$ The variations of collision radii $(\sigma)$ describe the dependence of oxygen sensitivity on molecular structures of OSPs. OSPs with high values of $\sigma$ should be more sensitive to oxygen.

$$
\frac{I_{0}}{I}=\frac{\tau_{0}}{\tau}=1+\frac{4 \pi \alpha N_{\mathrm{A}}}{1000}\left(P_{\mathrm{O}_{2}}\right)\left(\sigma \tau_{0}\right) p_{\mathrm{O}_{2}}
$$

According to eqn (3), the ratio of collision radii $\left(\sigma_{1} / \sigma_{2}\right)$ between two OSPs was obtained by the expression (eqn (4)), reads as

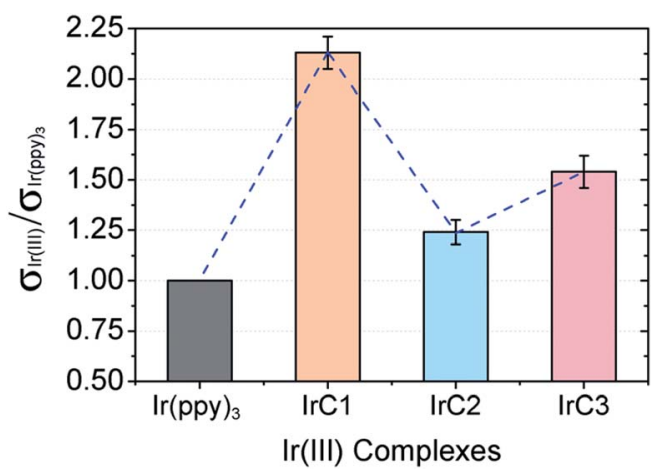

Fig. 5 The ratios of collision radii for $\operatorname{IrC} 1-\operatorname{IrC} 3$ versus $\operatorname{Ir}(\mathrm{ppy})_{3}$.

$$
\frac{\sigma_{1}}{\sigma_{2}}=\frac{\left[\left(\frac{I_{0}}{I}\right)_{1}-1\right] \tau_{2}}{\left[\left(\frac{I_{0}}{I}\right)_{2}-1\right] \tau_{1}}
$$

The ratios of collision radii between IrC1-IrC3 and $\operatorname{Ir}(\mathrm{ppy})_{3}\left(\sigma_{\operatorname{Ir}(\mathrm{III})} / \sigma_{\mathrm{Ir}(\mathrm{ppy})_{3}}\right)$ represented the collision radius variations of OSPs. With luminescent decay times, the $\sigma_{\operatorname{Ir}(\text { III) }} /$ $\sigma_{\operatorname{Ir}(\text { ppy })_{3}}$ have been calculated by measuring data of $I_{0}$ and $I_{100}$ five times in parallel (Table $\mathrm{S} 2$, see ESI $\dagger$ ). The ratios of collision radii were $2.13 \pm 0.08$ for $\sigma_{\operatorname{IrC} 1} / \sigma_{\operatorname{Ir}(\mathrm{ppy})_{3}}, 1.24 \pm 0.06$ for $\sigma_{\operatorname{IrC} 2} / \sigma_{\operatorname{Ir}(\text { ppy })_{3}}$, and $1.54 \pm 0.08$ for $\sigma_{\operatorname{IrC} 3} / \sigma_{\operatorname{Ir}(\text { ppy })_{3}}$, respectively, with the sequence of $\operatorname{IrC1}>\operatorname{IrC3}>\operatorname{IrC2}>\operatorname{Ir}(\text { ppy })_{3}$ (Fig. 5). In contrast to $\operatorname{Ir}(\mathrm{ppy})_{3}, \sigma$ of IrC1 was obviously increased by TPA moieties. And in comparison with IrC1, the introduction of $\mathrm{Cz} 1$ and $\mathrm{Cz} 2$ moieties markedly decreased the collision radii of IrC2 and IrC3, respectively.

In this research, the delocalization of spin populations (DSPs) was for the first time applied to confirm the collision radius variations of $\operatorname{Ir}(\mathrm{III})$ complexes. The spin densities of $\mathrm{T}_{1}$ state IrC1-IrC3 and $\operatorname{Ir}(\mathrm{ppy})_{3}$ were calculated using unrestricted DFT calculations (B3LYP level, mixed basis sets of 631G* and LanL2DZ) (Fig. 6 and Table S3, see ESI $\dagger$ ). ${ }^{49,50}$ The spin-density contours of $\operatorname{IrC1}-\mathbf{I r C} 3$ and $\operatorname{Ir}(\mathrm{ppy})_{3}$ were dominated by p orbitals with spin population $P_{\text {spin }}$ (percentages of

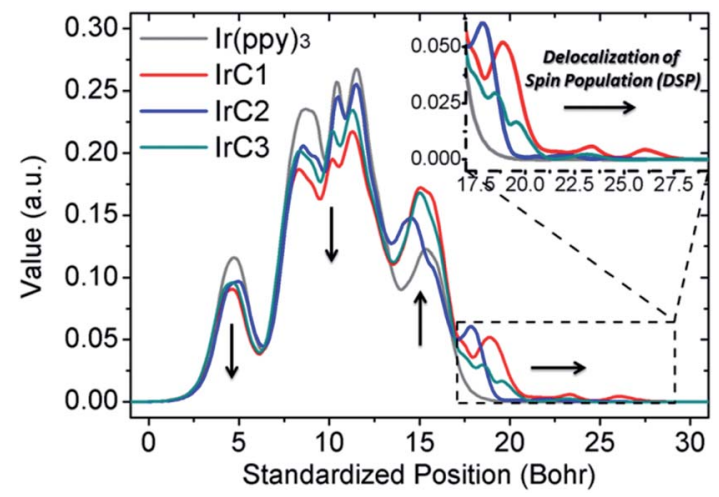

Fig. 7 Spin-density integral curves of the optimized $T_{1}$-state geometry of $\operatorname{IrC} 1-\operatorname{IrC} 3$ and $\operatorname{Ir}(\mathrm{ppy})_{3}$ along the $Z$ axis.
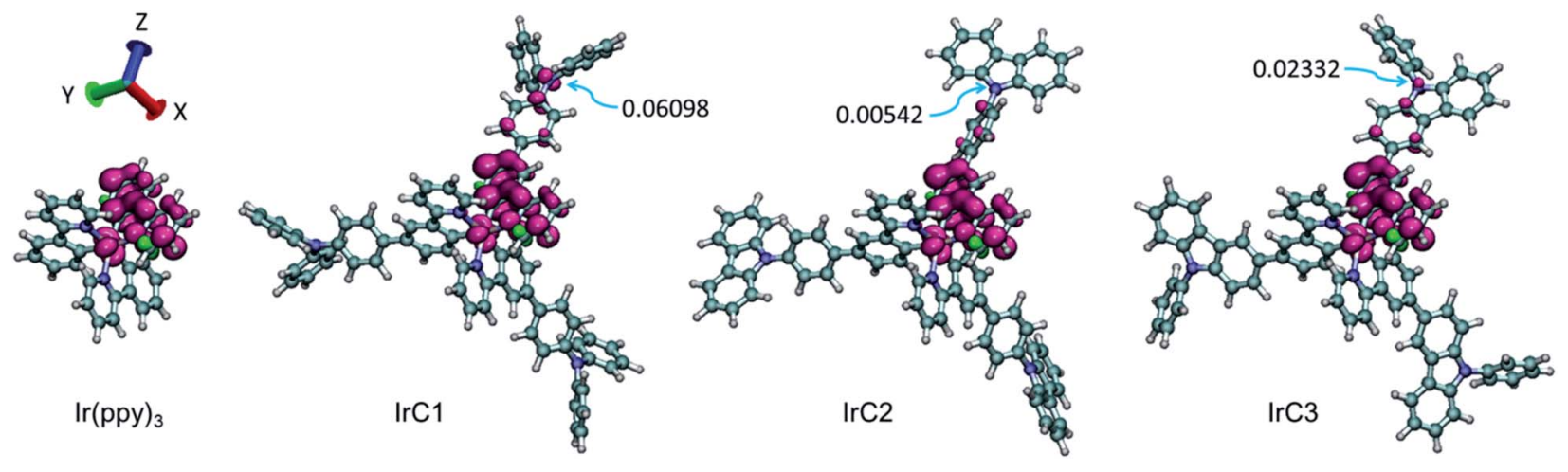

Fig. 6 Spin-density contours (0.003 a.u.) of $\operatorname{IrC} 1-\operatorname{IrC} 3$ and $\operatorname{Ir}(\mathrm{ppy})_{3}$. Magenta and green contours mean positive and negative phase. Arrows exhibited the spin population variations of on $\mathrm{N}$ atoms. 
spin population, $P_{\text {spin } \%)}$ of $1.66310(83.15 \%), 1.59881$ (79.94\%), $1.62016(81.00 \%)$ and 1.55760 (77.88\%), respectively. One of intraligands of Ir(III) complexes significantly contributed the spin-orbital contours. Remarkable DSPs were found on the TPA, Cz1, and Cz2 moieties with $P_{\text {spin }}\left(P_{\text {spin\% }}\right)$ of 0.23210 (11.61\%), 0.08862 (4.43\%), and 0.13201 (6.60\%), respectively (Table S3, see ESI $\dagger$ ). TPA moieties caused more intense DSPs than $\mathrm{Cz}$ moieties. The DSPs could be visually observed on the spin-density contours of $\mathrm{N}$ atoms on TPA, Cz1, and Cz2 moieties with $P_{\text {spin }}$ of $0.06098,0.00542$, and 0.02332 , respectively (Fig. 6). The spin-density integral curves of IrC1-IrC3 and $\operatorname{Ir}(\text { ppy) })_{3}$ were plotted along $Z$ axis (Fig. 7). ${ }^{\mathbf{9}}$ Compared with $\operatorname{Ir}(\text { ppy })_{3}$, spin population on $\operatorname{Ir}($ III) atoms and 2-phenylpyridine moieties of IrC1-IrC3 declined in the range of 0 to $13 \mathrm{bohr}$, and then increased from 13 bohr to $27.5 \mathrm{bohr}$ which exhibited intense DSPs on TPA, Cz1, and Cz2 moieties.

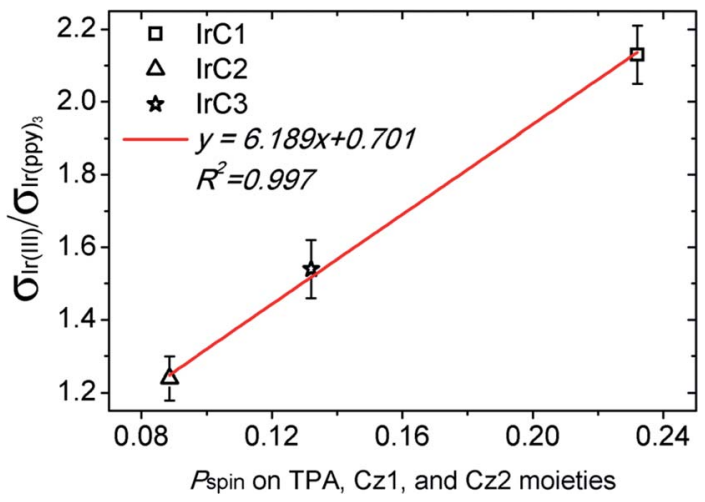

Fig. 8 The linear fitting curve between the ratios of collision radii $\left(\sigma_{\operatorname{lr}(\mathrm{III})} / \sigma_{\operatorname{lr}(\mathrm{ppy})_{3}}\right)$ and the spin population $\left(P_{\text {spin }}\right)$ of IrC1-IrC3.
Notably, considerable DSPs were demonstrated on TPA moieties than $\mathrm{Cz} 1$ and $\mathrm{Cz} 2$ moieties in the range of 17.5 to 27.5 bohr (Fig. 7). The integral curves confirmed the collision radius variations of Ir(III) complexes in Fig. 5 .

To demonstrate the relationship between the collision radius variations and the DSPs of $\operatorname{Ir}(\mathrm{III})$ complexes. The ratios of collision radii $\left(\sigma_{\operatorname{Ir}(\mathrm{III})} / \sigma_{\left.\operatorname{Ir}(\mathrm{ppy})_{3}\right)}\right)$ and the spin population $\left(P_{\text {spin }}\right)$ on TPA, Cz1, and Cz2 moieties of IrC1-IrC3 were fitted with linearity (Fig. 8). Strong linear correlations between the ratios of collision radii and $P_{\text {spin }}$ were apparent with $R^{2}$ of 0.997. Hence, the DSPs could be the descriptor for the dependence of oxygen sensitivity on the molecular structure of $\operatorname{Ir}(\mathrm{III})$ complexes. In comparison with $\operatorname{Ir}(\mathrm{ppy})_{3}$, introduction of TPA and $\mathrm{Cz}$ moieties effectively improved the DSPs on intraligands resulting in increase of collision radii of $\operatorname{Ir}(\mathrm{III})$ complexes. Despite the upward tendency of luminescent

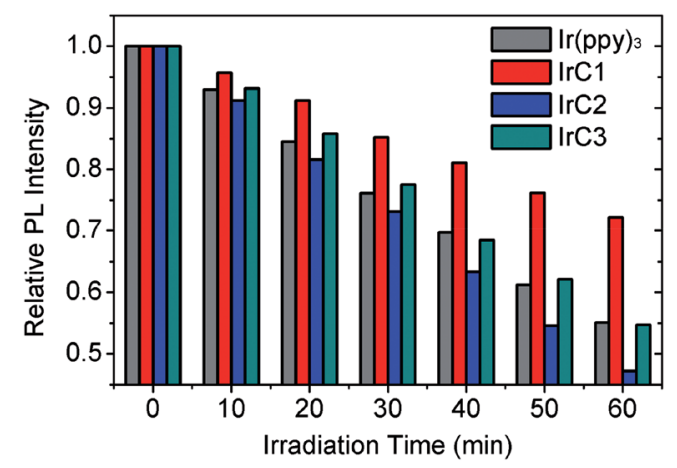

Fig. 10 Luminescent attenuation of $\operatorname{Ir}($ III) films under continuous irradiation.

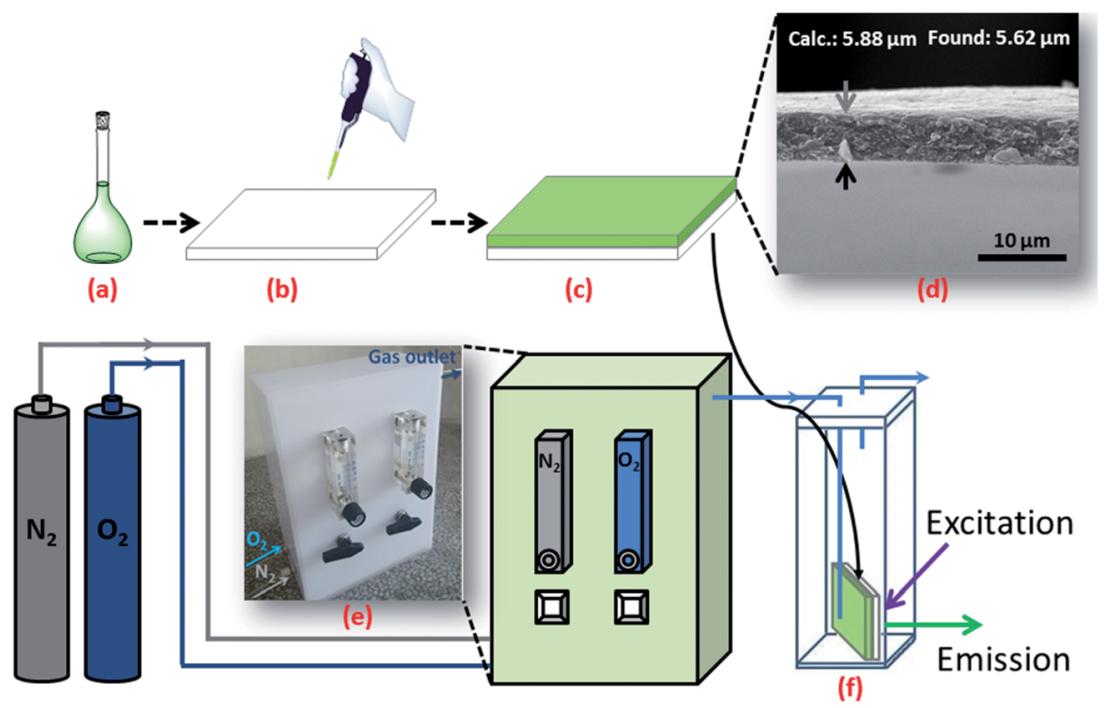

Fig. 9 Schematic illustration for the fabrication of $\operatorname{IrC1}-\mathrm{EC}$ film (0.5 wt\%) as sample and oxygen sensing measurements. (a) EC (9.95 mg) and THF $(0.90 \mathrm{~mL})$ were mixing with $0.10 \mathrm{~mL}$ IrC1-THF solution $\left(0.5 \mathrm{mg} \mathrm{mL}^{-1}\right)$. (b) The mixture $(0.10 \mathrm{~mL})$ was painted on a vitreous quartz sheet $(S=1.54$ $\mathrm{mm}^{2}$ ). (c) For the formation of the thin film, the solution was volatilized for 1 day at room temperature. (d) The SEM cross profile of IrC1-EC film. (e) Two tube flowmeters for the mixture of oxygen and nitrogen. (f) The IrC1-EC film on the vitreous quartz sheet was put in a cuvette for oxygen sensing measurements. 
decay times from IrC1 to IrC3, the increase of collision radius of $\mathbf{I r C 1}$ resulted in outstanding oxygen sensitivity.

\subsection{Photostability measurements}

The photostability of OSPs is always of great concern for practical applications such as high-light densities determination or long-time continuous monitoring of oxygen. In this work, easily available supporting matrix ethyl cellulose (EC) was applied to immobilize $\operatorname{Ir}(\mathrm{III})$ complexes, respectively (Fig. 9a-c). The thickness of EC films is $5.62 \mu \mathrm{m}$ (Fig. 9d). $\operatorname{Ir}(\mathrm{III})$ films were irradiated with Xe lamp under high power density of $27.3 \mathrm{~W} \mathrm{~m}^{-2}$ in air. And photostabilities of $\operatorname{Ir}(\mathrm{III})$ films were measured in $\mathrm{N}_{2}$ every 10 minutes. ${ }^{51}$ The data in Fig. 10 indicated that emission intensities of Ir(III) films were attenuated through continuous irradiation. IrC1 demonstrated higher photostability than that of $\operatorname{Ir}(\text { ppy })_{3}, \operatorname{IrC} 2$ and IrC3. About $27.8 \%$ of IrC1, $52.8 \%$ of IrC2, $45.3 \%$ of $\operatorname{IrC} 3$, and $44.9 \%$ of $\operatorname{Ir}(\mathrm{ppy})_{3}$ were destroyed after $60 \mathrm{~min}$ of irradiation. The photostabilities were in the sequence of $\operatorname{IrC1}>\operatorname{Ir}(\text { ppy })_{3} \approx$ IrC3 $>$ IrC2. And the sequence was correlated well with the order of excited-state oxidation potentials $\left(E_{\mathrm{ox}}^{*}\right)$ in Table 2, which determined the photo-oxidation reactivity of OSPs. ${ }^{46}$ Thus, the introduction of TPA moieties raises $E_{\text {ox }}^{*}$ which makes IrC1 more stable to continuous irradiation.

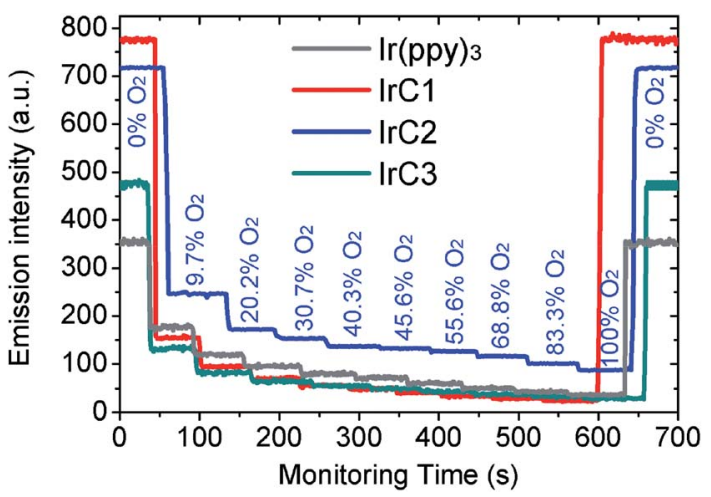

Fig. 11 Time-dependent luminescent responses of Ir(III) films with incremental concentration of oxygen.

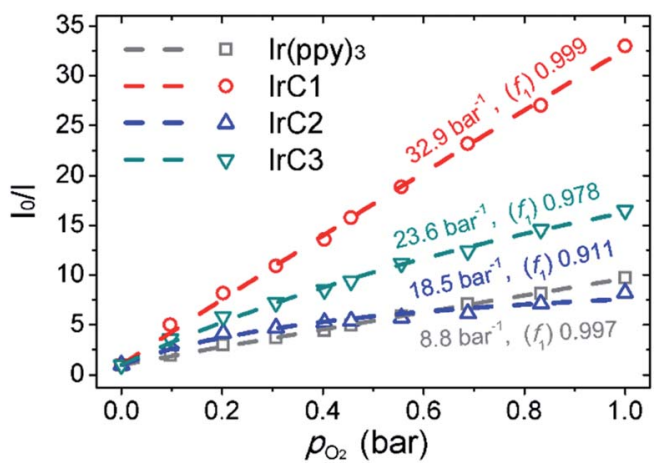

Fig. 12 SVPs for Ir(III) oxygen sensing films (fitted by two-site model).

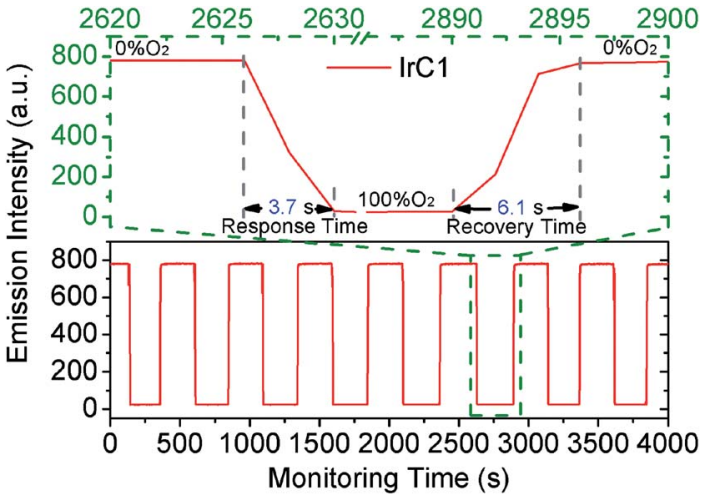

Fig. 13 Reversibility trace curve of IrC1-EC film to $0 \% \mathrm{O}_{2} / 100 \% \mathrm{O}_{2}$ saturation cycles in $4000 \mathrm{~s}$.

\subsection{Real-time monitoring of oxygen}

The luminescent responses of $\operatorname{Ir}(\mathrm{III})$ films were studied by gradually increasing concentration of $\mathrm{O}_{2}$. The $\mathrm{Ir}(\mathrm{III})$ films in $0 \% \mathrm{O}_{2}\left(100 \% \mathrm{~N}_{2}\right)$ exhibited intense room-temperature phosphorescence. And emission intensities of Ir(III) films were attenuated stepwise with incremental concentration of $\mathrm{O}_{2}$ (Fig. 11). $K_{\mathrm{SV}}^{\text {app }}$ and $f_{1}$ values were summarized in Fig. 12 and Table S4 (see ESI $\dagger$ ) which were fitted by eqn (2). The $I_{0} / I_{100}$ for $\operatorname{Ir}(\mathrm{III})$ films of IrC1, IrC2, IrC3, and $\operatorname{Ir}(\mathrm{ppy})_{3}$ were 33.0, 8.2, 16.5 , and 9.7 with $K_{\mathrm{SV}}^{\mathrm{app}}$ of $32.9 \mathrm{bar}^{-1}, 18.5 \mathrm{bar}^{-1}, 23.6 \mathrm{bar}^{-1}$ and $8.8 \mathrm{bar}^{-1}$. The IrC1-EC film exhibited outstanding oxygen sensitivity than that of other films. And the sequence of oxygen sensitivities was $\operatorname{IrC1}>\operatorname{IrC3}>\operatorname{IrC2}>\operatorname{Ir}(\text { ppy })_{3}$, which was consistent with the sequence of oxygen sensitivities in THF (Fig. 4). The $f_{1}$ values of IrC1 (0.999), IrC3 (0.978), and $\operatorname{Ir}(\text { ppy })_{3}$ (0.997) films were higher than that of $\operatorname{IrC2}(0.911)$ which showed considerable linearity and perfect microhomogeneity and resulted in increased oxygen sensitivities.

\subsection{Operational stability of oxygen sensing film}

Because of the excellent oxygen sensing performance and high photostability, the operational stability of IrC1-EC film was measured by switching $\mathrm{O}_{2}$ and $\mathrm{N}_{2}$ atmospheres in $4000 \mathrm{~s}$ (Fig. 13). The values of $I_{0}$ and $I_{100}$ was constant and the cycles of quenching and recovery were perfectly reversible with no attenuation of original emission intensity which exhibited excellent operational stability. The response time of $3.7 \mathrm{~s}$ and recovery time of $6.1 \mathrm{~s}$ (96.6\% recovery of original intensity) indicated quick responses of IrC1-EC film to molecular oxygen. Therefore, IrC1-EC film demonstrated outstanding photostability and operational stability which satisfied online continuous monitoring of molecular oxygen.

\section{Conclusions}

In summary, new TPA and $\mathrm{Cz}$ moieties contained $\operatorname{Ir}(\mathrm{III})$ complexes IrC1, IrC2, and IrC3 were prepared and fully characterized as OSPs for luminescent sensing of oxygen. The ratios of collision radii $\left(\sigma_{\operatorname{Ir}(\mathrm{III})} / \sigma_{\mathrm{Ir}(\mathrm{ppy})_{3}}\right)$ of $\operatorname{IrC} 1-\operatorname{IrC} 3$ to $\operatorname{Ir}(\mathrm{ppy})_{3}$ were 2.13 $\pm 0.08,1.24 \pm 0.06$, and $1.54 \pm 0.08$, respectively. Remarkable 
DSPs were found on the TPA, Cz1, and Cz2 moieties with the spin population (percentages of spin population) of 0.23210 (11.61\%), 0.08862 (4.43\%), and 0.13201 (6.60\%), respectively. Strong linear correlations between the ratios of collision radii $\left(\sigma_{\operatorname{Ir}(\text { III })} / \sigma_{\text {Ir(ppy })_{3}}\right)$ and the spin population on TPA and Cz moieties of IrC1-IrC3 were apparent with $R^{2}$ of 0.997 . The DSPs could be used to describe the dependence of oxygen sensitivity on the molecular structure of Ir(III) complexes. Introduction of TPA moieties could strongly improve photostability of $\operatorname{Ir}(\mathrm{III})$ complexes to reduce photo-oxidation. And fast response and recovery times of IrC1-EC film were obtained at $3.7 \mathrm{~s}$ and $6.1 \mathrm{~s}$ with no attenuation of original emission intensity in $4000 \mathrm{~s}$ which exhibited the excellent reversibility and operational stability. The results provide new concepts and technical supports for the design of high-performance luminescent sensors for monitoring of oxygen.

\section{Conflicts of interest}

There are no conflicts to declare.

\section{Acknowledgements}

The author thank the financial supports of Liaoning Shihua University (2017XJJ-001, 2016XJJ-099), the Education Department of Liaoning Province (L2017LQN007), the National Natural Science Foundation of China (21703135), and the Natural Science Foundation of the Department of Education of Shaanxi Province (17JS034).

\section{Notes and references}

1 P. Di Mascio, G. R. Martinez, S. Miyamoto, G. E. Ronsein, M. H. G. Medeiros and J. Cadet, Chem. Rev., 2019, 119, 2043.

2 M. Quaranta, S. M. Borisov and I. Klimant, Bioanal. Rev., 2012, 4, 115.

3 D. B. Papkovsky and R. I. Dmitriev, Chem. Soc. Rev., 2013, 42, 8700.

4 K. Iman and M. Shahid, New J. Chem., 2019, 43, 1094.

5 X. Zhang, L. Huang, Q. Wang and S. Dong, J. Mater. Chem. A, 2017, 5, 18839.

6 X. D. Wang and O. S. Wolfbeis, Chem. Soc. Rev., 2014, 43, 3666.

7 X. Lu and M. A. Winnik, Chem. Mater., 2001, 13, 3449.

8 Y. Amao, Microchim. Acta, 2003, 143, 1.

9 M. Marín-Suárez, B. F. E. Curchod, I. Tavernelli, U. Rothlisberger, R. Scopelliti, I. Jung, D. Di Censo, M. Grätzel, J. F. Fernández-Sánchez, A. FernándezGutiérrez, M. K. Nazeeruddin and E. Baranoff, Chem. Mater., 2012, 24, 2330.

10 M. Li, B. Zheng, D. Luo, H. Sun, N. Wang, Y. Huang, J. Dai, D. Xiao, S.-J. Su and Z. Lu, Chem. Commun., 2015, 51, 1926.

11 V. Y. Vasilyev, N. B. Morozova, T. V. Basova, I. K. Igumenov and A. Hassan, RSC Adv., 2015, 5, 32034.

12 P. Majumdar, X. Yuan, S. Li, B. Le Guennic, J. Ma, C. Zhang, D. Jacquemin and J. Zhao, J. Mater. Chem. B, 2014, 2, 2838.
13 L. Liu, D. Huang, S. M. Draper, X. Yi, W. Wu and J. Zhao, Dalton Trans., 2013, 42, 10694.

14 C. Arunkumar, F. R. Kooriyaden, X. Zhang, S. Sujatha and J. Zhao, New J. Chem., 2017, 41, 4908.

15 H. Guo, L. Zhu, C. Dang, J. Zhao and B. Dick, Phys. Chem. Chem. Phys., 2018, 20, 17504.

16 K. Xu, J. Zhao and E. G. Moore, Photochem. Photobiol. Sci., 2016, 15, 995.

17 Y. Che, W. Yang, G. Tang, F. Dumoulin, J. Zhao, L. Liu and Ü. İşci, J. Mater. Chem. C, 2018, 6, 5785.

18 S. M. Borisov, G. Nuss, W. Haas, R. Saf, M. Schmuck and I. Klimant, J. Photochem. Photobiol., A, 2009, 201, 128.

19 Y. Liu, H. Guo and J. Zhao, Chem. Commun., 2011, 47, 11471. 20 Y. Xing, C. Liu, J.-H. Xiu and J.-Y. Li, Inorg. Chem., 2015, 54, 7783.

21 P. Lehner, C. Staudinger, S. M. Borisov and I. Klimant, Nat. Commun., 2014, 5, 4460.

22 O. S. Wolfbeis, J. Mater. Chem., 2005, 15, 2657.

23 M. Quaranta, S. M. Borisov and I. Klimant, Bioanal. Rev., 2012, 4, 115.

24 V. V. Vasil'ev and S. M. Borisov, Sens. Actuators, B, 2002, 82, 272.

25 T. Ishiji, K. Kudo and M. Kaneko, Sens. Actuators, B, 1994, 22, 205.

26 Y. Amao, K. Asai, T. Miyashita and I. Okura, Polym. Adv. Technol., 2000, 11, 705.

27 Y. Amao, K. Asai, I. Okura, H. Shinohara and H. Nishide, Analyst, 2000, 125, 1911.

28 Y. Amao, T. Miyashita and I. Okura, Anal. Chim. Acta, 2000, 421, 167.

29 W. Wu, W. Wu, S. Ji, H. Guo and J. Zhao, Dalton Trans., 2011, 40, 5953.

30 W. Wu, J. Sun, S. Ji, W. Wu, J. Zhao and H. Guo, Dalton Trans., 2011, 40, 11550.

31 C. Liu, X. Song, Z. Wang and J. Qiu, ChemPlusChem, 2014, 79, 1472.

32 C. Liu, X. Song, X. Rao, Y. Xing, Z. Wang, J. Zhao and J. Qiu, Dyes Pigm., 2014, 101, 85.

33 Y. Xing, C. Liu, X. Song and J. Li, J. Mater. Chem. C, 2015, 3, 2166.

34 L. Deng, T. Zhang, R. Wang and J. Li, J. Mater. Chem., 2012, 22, 15910.

35 J. Li, R. Wang, R. Yang, W. Zhou and X. Wang, J. Mater. Chem. C, 2013, 1, 4171.

36 J. Li, T. Zhang, Y. Liang and R. Yang, Adv. Funct. Mater., 2013, 23, 619.

37 N. Li, Y. Fang, L. Li, H. Zhao, Y. Quan, S. Ye, Q. Fan and W. Huang, J. Lumin., 2018, 199, 465.

38 J. Hu, X. Zhang, D. Zhang, X. Cao, T. Jiang, X. Zhang and Y. Tao, Dyes Pigm., 2017, 137, 480.

39 P. Agarwala and D. Kabra, J. Mater. Chem. A, 2017, 5, 1348.

40 R. Maragani, R. Misra, M. S. Roy, M. K. Singh and G. D. Sharma, Phys. Chem. Chem. Phys., 2017, 19, 8925.

41 S. Soman, S. C. Pradhan, M. Yoosuf, M. V. Vinayak, S. Lingamoorthy and K. R. Gopidas, J. Phys. Chem. C, 2018, 122, 14113. 
42 L. Di, Y. Xing, X. Wang, D. Zheng, Y. Yang and F. Li, RSC Adv., 2018, 8, 41040.

43 J. Zhao, W. Wu, J. Sun and S. Guo, Chem. Soc. Rev., 2013, 42, 5323.

44 Q. Li, C. Shi, M. Huang, X. Wei, H. Yan, C. Yang and A. Yuan, Chem. Sci., 2019, 10, 3257.

45 W. Wu, H. Guo, W. Wu, S. Ji and J. Zhao, Inorg. Chem., 2011, 50, 11446.

46 W. Wai-SanáLee and K. ShingáChan, J. Mater. Chem., 1993, 3, 1031 .
47 W. Wu, J. Sun, X. Cui and J. Zhao, J. Mater. Chem. C, 2013, 1, 4577.

48 E. Carraway, J. Demas and B. DeGraff, Langmuir, 1991, 7, 2991.

49 T. Lu and F. Chen, J. Comput. Chem., 2012, 33, 580.

50 W. Humphrey, A. Dalke and K. Schulten, J. Mol. Graphics, 1996, 14, 33.

51 S. M. Borisov, R. Pommer, J. Svec, S. Peters, V. Novakova and I. Klimant, J. Mater. Chem. C, 2018, 6, 8999. 